\title{
Phylogenetic relationships of the North-eastern Atlantic and Mediterranean forms of Atherina (Pisces, Atherinidae)
}

\author{
S.M. Francisco ${ }^{\mathrm{a}, \mathrm{b}, *}$, L. Congiu $^{\mathrm{c}}$, S. Stefanni $^{\mathrm{d}}$, R. Castilho $^{\mathrm{e}}$, A. Brito ${ }^{\mathrm{f}}$, P.P. Ivanova ${ }^{\mathrm{g}}$, \\ A. Levy ${ }^{\text {a }}$, H. Cabral ${ }^{\text {h }}$, G. Kilias ${ }^{i}$, I. Doadrio ${ }^{j}$, V.C. Almada ${ }^{\text {a }}$ \\ ${ }^{a}$ UIE, Instituto Superior de Psicologia Aplicada, Rua Jardim do Tabaco 34, 1149-041 Lisboa, Portugal

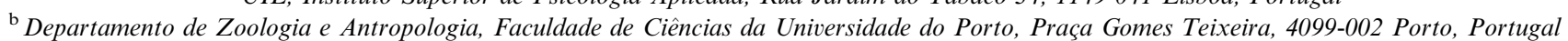 \\ ${ }^{\mathrm{c}}$ Dipartamento di Biologia, Università di Padova, Via U. Bassi 58/B, 35121 Padova, Italy \\ d IMAR/DOP, University of the Azores, Cais Sta Cruz, 9901-862 Horta, Azores, Portugal \\ ${ }^{\text {e } C e n t r o ~ d e ~ C i e ̂ n c i a s ~ d o ~ M a r ~ d o ~ A l g a r v e, ~ U n i v e r s i d a d e ~ d o ~ A l g a r v e, ~ C a m p u s ~ d e ~ G a m b e l a s, ~ 8005-139 ~ F a r o, ~ P o r t u g a l ~}$ \\ ${ }^{\mathrm{f}}$ Universidad de La Laguna, Dpto. Biología Animal (Ciencias Marinas), Av. Astrofísico Francisco Sánchez s/n, 38206 La Laguna, \\ Tenerife, Islas Canarias, Spain \\ ${ }^{\mathrm{g}}$ Institute of Fishing Resources, Boulevard Primorski 4, P.O. Box 72, 9000 Varna, Bulgaria \\ ${ }^{\mathrm{h}}$ Instituto de Oceanografia, Faculdade de Ciências da Universidade de Lisboa, Campo Grande, 1749-016 Lisboa, Portugal \\ ${ }^{\mathrm{i}}$ Department of Biology, Division of Genetics, Cell Biology and Development, University of Patras, Rion-Patras 26500, Greece \\ ${ }^{\mathrm{j}}$ Museo National de Ciencias Naturales. José Gutiérrez Abascal 2, 28006 Madrid, Spain
}

Received 9 December 2007; accepted 11 December 2007

Available online 31 January 2008

\section{Introduction}

The genus Atherina (Sand-smelts) is distributed in the Eastern Atlantic Ocean and Mediterranean Sea, extending south along the African coast into the Indian Ocean (Quignard and Pras, 1986). It is a genus of small inshore fishes with many populations living in brackish and freshwater.

The taxonomy of the genus has been troublesome due to the intraspecific variability of some of its species, the overlap of characters among many of them and because many nominal species were apparently described based on individuals originating from different localities. After the revision of Kiener and Spillman (1969) only three species were accepted for the Mediterranean and divided in two subgenera: Atherina including Atherina hepsetus (Linnaeus 1758) and Hepsetia including Atherina boyeri (Risso 1810) and Atherina presbyter (Cuvier 1829). A. hepsetus is restricted to the Mediterranean, A. presbyter occurs mainly in the North-eastern Atlantic and very sporadically in the Mediterranean, and $A$. boyeri occurs in both areas. In addition to these species, two others have been recognized: A. lopezi-

\footnotetext{
* Corresponding author. Address: UIE, Instituto Superior de Psicologia Aplicada, Rua Jardim do Tabaco 34, 1149-041 Lisboa, Portugal. Fax: +351218860954.

E-mail address: sara_francisco@ispa.pt (S.M. Francisco).
}

ana confined to the Gulf of Guinea, and A. breviceps in the South-eastern Atlantic and ranging into the Indian Ocean along the East coast of Africa (Maugé, 1990). Some authors did not accept this revised classification and in the past 20 years several studies based on morphological traits and mitochondrial DNA have suggested some modifications or proposed new species among $A$. boyeri. A summary of the more relevant changes in the taxonomic history of Mediterranean Atherina is presented in Table 1, together with the proposals emerging from the present work.

In the present study 515 specimens ranging from the Wadden Sea to the Canary Islands and the Azores Islands, and eastwards to the Black Sea and a freshwater basin in Turkey were analyzed in order to investigate the phylogenetic relationships within the genus Atherina occurring in the North-eastern Atlantic and Mediterranean. Two mitochondrial DNA markers were analyzed: a fragment of the slowly evolving $12 \mathrm{~S}$ rDNA gene and a fragment of the rapidly evolving control region (CR).

\section{Materials and methods}

A total of 515 fish of the genus Atherina were obtained from several locations in the European Atlantic coast and rivers, North Sea, Canary Islands, Azores Islands, 
Table 1

Simplified taxonomical history of Atherina boyeri

\begin{tabular}{llll}
\hline & Lagoon form & Marine punctuated form & Marine non-punctuated form \\
\hline Early studies & Several species described (up to 20 in the Mediterranean Sea) & \\
e.g. Gourret (1894) & A. mochon & Not clearly described & A. boyeri \\
Kiener and Spillman (1969) revision & $\begin{array}{l}\text { A. boyeri } \\
\text { Kottelat (1997) }\end{array}$ & A. boyeri & A. mochon \\
Trabelsi et al. (2002b,a) & A. lagunae & A. punctata & A. boyeri \\
Klossa-Kilia et al. (2007, 2002) & Lagoon A. boyeri & Not mentioned & Marine A. boyeri \\
Astolfi et al. (2005) & A. boyeri & Punctuated form & Non-punctuated form \\
Present work & A. boyeri & Punctuated form & Non-punctuated form
\end{tabular}

${ }^{\text {a }}$ Species not formally described.

${ }^{\mathrm{b}}$ Present in coastal lagoons, brackish sections of estuaries and freshwater bodies.

Morocco, Mediterranean, Black Sea and Lake Sapanca in Turkey (Fig. 1 and Table 2).

Total genomic DNA extraction was performed on fin samples preserved in 96\% ethanol (Sambrook et al., 1989). To amplify the two mitochondrial regions the following primer pairs were used: L-pro1 and H-DL1 (Ostellari et al., 1996) for the CR, and 12SFor and 12SRev (Henriques et al., 2002) for the12S rDNA. PCR and sequencing were performed as service by Macrogen (Seoul, Korea) and details may be requested from the authors. All sequences were aligned using Clustal X (Thompson et al., 1997).

Statistical and phylogenetic analyses were performed using PAUP* 4.0b (Swofford, 2000) and MRBAYES 3.1 (Huelsenbeck and Ronquist, 2001; Ronquist and Huelsenbeck, 2003). The sequences of Hypoatherina tsurugae and
Melanotaenia lacustris (Accession Nos. AP004420 and NC_004385) were used as outgroups.

As the Partition-homogeneity test (Farris et al., 1995) did not yield significant differences between the two fragments $(P=0.520)$, a set of concatenated sequences was used.

MODELTEST 3.7 (Posada and Crandall, 1998) was used to select the best model of evolution to be used in Neighbour-joining analysis (NJ). The selected model was TrN + I + G (Tamura and Nei, 1993). A Maximum Parsimony (MP) analysis was performed with heuristic search and transition/transversion rate $(t i / t v)$ of 1,5 and 10 were used. Robustness of the inferred MP and NJ trees was tested by using bootstrap replicates (Felsenstein, 1985).

Bayesian analysis was performed using MCMC as implemented in MRBAYES with four independent runs

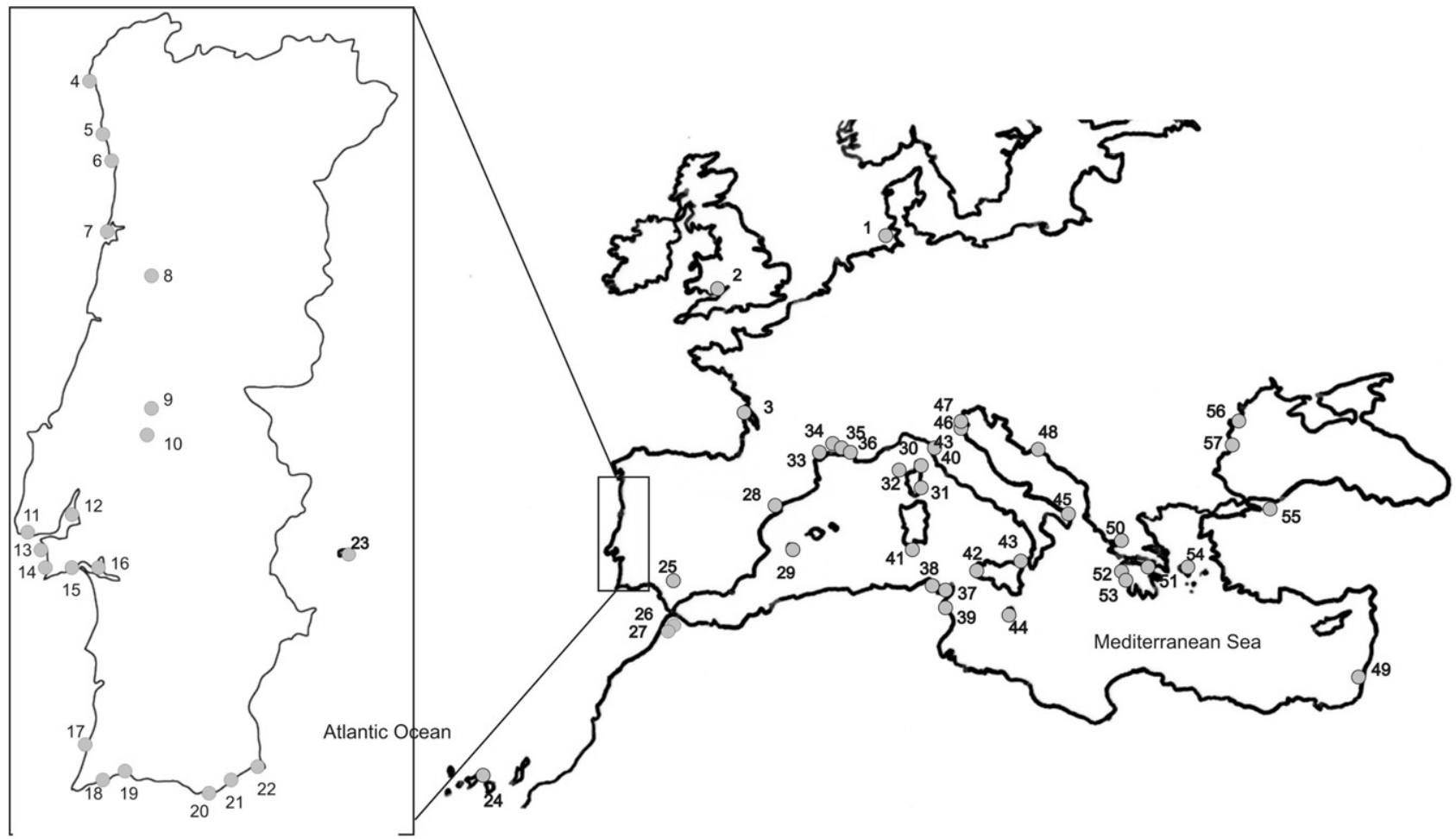

Fig. 1. Map of sampling locations. The location numbers are as in Table 2. 
Table 2

Collection sites and number of Atherina individuals used in the present work

\begin{tabular}{|c|c|c|c|c|c|c|c|c|c|c|c|c|c|}
\hline \multirow{2}{*}{$\begin{array}{l}\text { Collection } \\
\text { site }\end{array}$} & & \multirow{2}{*}{$\begin{array}{l}\text { Number in } \\
\text { Fig. } 1\end{array}$} & \multirow[t]{2}{*}{$N$} & \multicolumn{2}{|c|}{ A. presbyter } & \multicolumn{2}{|c|}{ A. hepsetus } & \multicolumn{2}{|c|}{ A. boyeri } & \multicolumn{2}{|c|}{ Punctuated fish } & \multicolumn{2}{|c|}{ Non-punctuated fish } \\
\hline & & & & $12 \mathrm{~S}$ & $\overline{\text { d-loop }}$ & $12 \mathrm{~S}$ & $\overline{\text { d-loop }}$ & $12 \mathrm{~S}$ & d-loop & $12 \mathrm{~S}$ & d-loop & $12 \mathrm{~S}$ & d-loop \\
\hline \multicolumn{14}{|l|}{ Atlantic } \\
\hline UK & Swansea & 2 & 3 & 2 & $3^{\mathrm{a}}$ & & & & & & & & \\
\hline France & Arcachon & 3 & 2 & 2 & $2^{\mathrm{a}}$ & & & & & & & & \\
\hline & Douro & 6 & 3 & 3 & & & & & & & & & \\
\hline & Aveiro & 7 & 24 & 3 & $24^{\mathrm{b}}$ & & & & & & & & \\
\hline & Mondego & 8 & 28 & & & & & 6 & $28^{\mathrm{b}}$ & & & & \\
\hline & Almonda (Tagus) & 9 & 21 & & & & & 5 & $21^{\mathrm{b}}$ & & & & \\
\hline & Boquilobo (Tagus) & 10 & 1 & & & & & & $1^{\mathrm{b}}$ & & & & \\
\hline & S. Pedro Estoril & 11 & 3 & & 3 & & & & & & & & \\
\hline & Sado & 16 & 10 & 2 & & & & 4 & 4 & & & & \\
\hline & Amoreira & 17 & 11 & 3 & & & & & & & & & \\
\hline & Lagos & 18 & 3 & 3 & & & & & & & & & \\
\hline & Arade & 19 & 26 & & 26 & & & & & & & & \\
\hline & Ilha-de-Faro & 20 & 6 & & & & & & 6 & & & & \\
\hline & Olhão & 21 & 1 & & 1 & & & & & & & & \\
\hline & Castro Marim & 22 & 20 & 3 & 19 & & & & 1 & & & & \\
\hline & (Santa Maria) & 23 & 6 & 6 & 6 & & & & & & & & \\
\hline \multirow[t]{2}{*}{ Spain } & (Tenerife) & 24 & 24 & 8 & 24 & & & & & & & & \\
\hline & Zonar & 25 & 10 & & & & & 2 & $10^{\mathrm{a}}$ & & & & \\
\hline \multirow[t]{2}{*}{ Morocco } & Sebou & 26 & 12 & & & & & 12 & 12 & & & & \\
\hline & Loukkos & 27 & 4 & & & & & 3 & 4 & & & & \\
\hline & Agde & 33 & 2 & & & & & & & 2 & 2 & & \\
\hline & Thau & 34 & 2 & & & & & & & & & 2 & 2 \\
\hline & Mauguio & 35 & 2 & & & & & 2 & 2 & & & & \\
\hline & Or & 36 & 10 & & & & & 2 & $10^{\mathrm{a}}$ & & & & \\
\hline Tunisia & Tunis & 37 & 6 & & & & & & $6^{\mathrm{a}}$ & & & & \\
\hline & Cap Zebib & 38 & 2 & & & & & & & & & 2 & 2 \\
\hline & Hergla & 39 & 2 & & & & & & & 2 & 2 & & \\
\hline Italy & Fucecchio & 40 & 10 & & & & & 3 & $10^{\mathrm{a}}$ & & & & \\
\hline & Cagliari & 41 & 13 & & & 1 & 3 & 3 & $10^{\mathrm{a}}$ & & & & \\
\hline & Marsala & 42 & 10 & & & & & 4 & $10^{\mathrm{a}}$ & & & & \\
\hline & Faro & 43 & 10 & & & & & 3 & $10^{\mathrm{a}}$ & & & & \\
\hline & Lampedusa & 44 & 2 & & & 1 & 2 & & & & & & \\
\hline & Acquatina & 45 & 10 & & & & & 3 & $10^{\mathrm{a}}$ & & & & \\
\hline & Scardovari & 46 & 10 & & & & & 3 & $10^{\mathrm{a}}$ & & & & \\
\hline & Chioggia & 47 & 22 & & & & & & 22 & & & & \\
\hline Croatia & Spalato & 48 & 13 & & & 2 & 3 & 4 & $10^{\mathrm{a}}$ & & & & \\
\hline Israel & $?$ & 49 & 3 & & & & & & & & & 3 & 3 \\
\hline Greece & Trichonidas & 50 & 3 & & & & & $3^{\mathrm{c}}$ & $3^{\mathrm{c}}$ & & & & \\
\hline & Korinthiakos & 51 & 8 & & & 4 & 4 & & & & & $4^{\mathrm{c}}$ & $4^{\mathrm{c}}$ \\
\hline
\end{tabular}


Table 2 (continued)

\begin{tabular}{|c|c|c|c|c|c|c|c|c|c|c|c|c|c|}
\hline \multirow{2}{*}{$\begin{array}{l}\text { Collection } \\
\text { site }\end{array}$} & & \multirow{2}{*}{$\begin{array}{l}\text { Number in } \\
\text { Fig. } 1\end{array}$} & \multirow[t]{2}{*}{$N$} & \multicolumn{2}{|c|}{ A. presbyter } & \multicolumn{2}{|c|}{ A. hepsetus } & \multicolumn{2}{|c|}{ A. boyeri } & \multicolumn{2}{|c|}{ Punctuated fish } & \multicolumn{2}{|c|}{ Non-punctuated fish } \\
\hline & & & & $12 \mathrm{~S}$ & d-loop & $12 \mathrm{~S}$ & d-loop & $12 \mathrm{~S}$ & d-loop & $12 \mathrm{~S}$ & d-loop & $12 \mathrm{~S}$ & d-loop \\
\hline & Kaiafas & 52 & 3 & & & & & $3^{\mathrm{c}}$ & $3^{c}$ & & & & \\
\hline & Kiparisia & 53 & 3 & & & & & & & & & $3^{\mathrm{c}}$ & $3^{\mathrm{c}}$ \\
\hline & Tinos & 54 & 3 & & & 3 & 3 & & & & & & \\
\hline \multicolumn{14}{|l|}{ Black sea } \\
\hline Turkey & Lake Sapanca & 55 & 5 & & & & & 4 & 5 & & & & \\
\hline Romania & Danube & 56 & 10 & & & & & 6 & $10^{\mathrm{a}}$ & & & & \\
\hline Bulgaria & $?$ & 57 & 15 & & & & & 3 & 15 & & & & \\
\hline
\end{tabular}

a Astolfi et al. (2005).

${ }^{\mathrm{b}}$ Francisco et al. (2006).

${ }^{c}$ Klossa-Kilia et al. (2007).

of four chains of 7,000,000 generations each, and considering two independent data partitions corresponding to each mitochondrial region. Topologies were sampled every 1000 generations, and a majority-rule consensus tree was estimated after discarding the first 4000 sampled generations.

The Kishino-Hasegawa test (Kishino and Hasegawa, 1989) was performed to examine the congruence between the MP and Bayesian trees.

After the different clades were identified, inter-clade distances were computed using the software package ARLEQUIN 3.1 (Excoffier et al., 2005).

\section{Results}

About 350 and $370 \mathrm{bp}$ of the $12 \mathrm{~S}$ and control region, respectively, were amplified. Among the 178 12S samples a total of 35 distinct haplotypes were found, while 495 samples of CR yielded 265 haplotypes (Table 3 in electronic supplements).

The NJ and MP trees presented the same topology. The Bayesian tree is shown in Fig. 2, along with bootstrap values for NJ and MP. The Kishino-Hasegawa test yielded no significant differences between the MP and Bayesian trees $(P=1.000)$. All inference methods are consistent with the monophyly of Atherina. Within the genus, the three inference methods recovered four major clades (A. presbyter) $A$. hepsetus, A. boyeri, punctuated and non-punctuated fish) supported with high bootstraps and posterior probabilities. Finally, all methods provide indications that two sister groups are present: one including the lineage $A$. presbyter/A. hepsetus, and other grouping the remaining major clades. However, the statistical support of this last group is not strong. Within this clade, relationships among punctuated, non-punctuated and $A$. boyeri could not be resolved by the present analysis. Within the $A$. presbyte/A. hepsetus main cluster, three subgroups are present: $A$. hepsetus, the fish from European Atlantic shores and the fish from the Macaronesian Islands. The monophyly of $A$. presbyter although presented in Fig. 2 lacks the support of the Bayesian analysis but it is supported by the other two methods.

While in A. presbyter, A. hepsetus, punctuated and nonpunctuated no geographical patterns were detected (except for the Canary and Azores Islands, as mentioned above), $A$. boyeri is subdivided in several distinct phylogroups corresponding to different geographical areas and confirming Astolfi et al. (2005) findings. A first subgroup includes fish from Tunisia and the Sicily channel which are deeply separated from all the others. A second subgroup includes all fish from the Western Mediterranean and adjacent Atlantic rivers and all but one samples from the Adriatic Sea. A third subgroup is composed by the Greek samples on one hand and by those from the Danube delta, the Black Sea and the freshwater samples of Lake Sapanca on the other. The relationships among these three subgroups are not yet fully resolved as shown by the polytomy yielded by NJ and MP methods.

Among group corrected $P$-distances expressed as percentage divergence average 3.87 for the $12 \mathrm{~S}$ and 16.31 for CR (Tables 4 and 5 in electronic supplements).

\section{Discussion}

\subsection{Taxonomical implications}

The present results are consistent with the monophyly of the genus Atherina from the North-eastern Atlantic and Mediterranean, and its subdivision in five clearly separated groups. These groups perfectly correspond to two already recognized species (A. hepsetus and A. presbyter) and to three additional lineages that emerge within $A$. boyeri sensu Kiener and Spillman (1969). Although these clades had been identified in previous studies (Table 1) based on restricted sampling areas, their presence across wide areas of the Mediterranean and their high genetic inter-clade distances (Tables 4 and 5 in electronic supplements) suggests that they likely correspond to valid species awaiting formal description.

The sister relationship between A. presbyter and A. hepsetus, previously suggested by Astolfi et al. (2005) is confirmed. Thus, another taxonomical implication of the present work is the non-validity of the subgenera Atherina and Hepsetia sensu Kiener and Spillman (1969). Our data revealed the existence of a cohesive group of $A$. presbyter from Portugal to Germany. The samples from the Canaries 


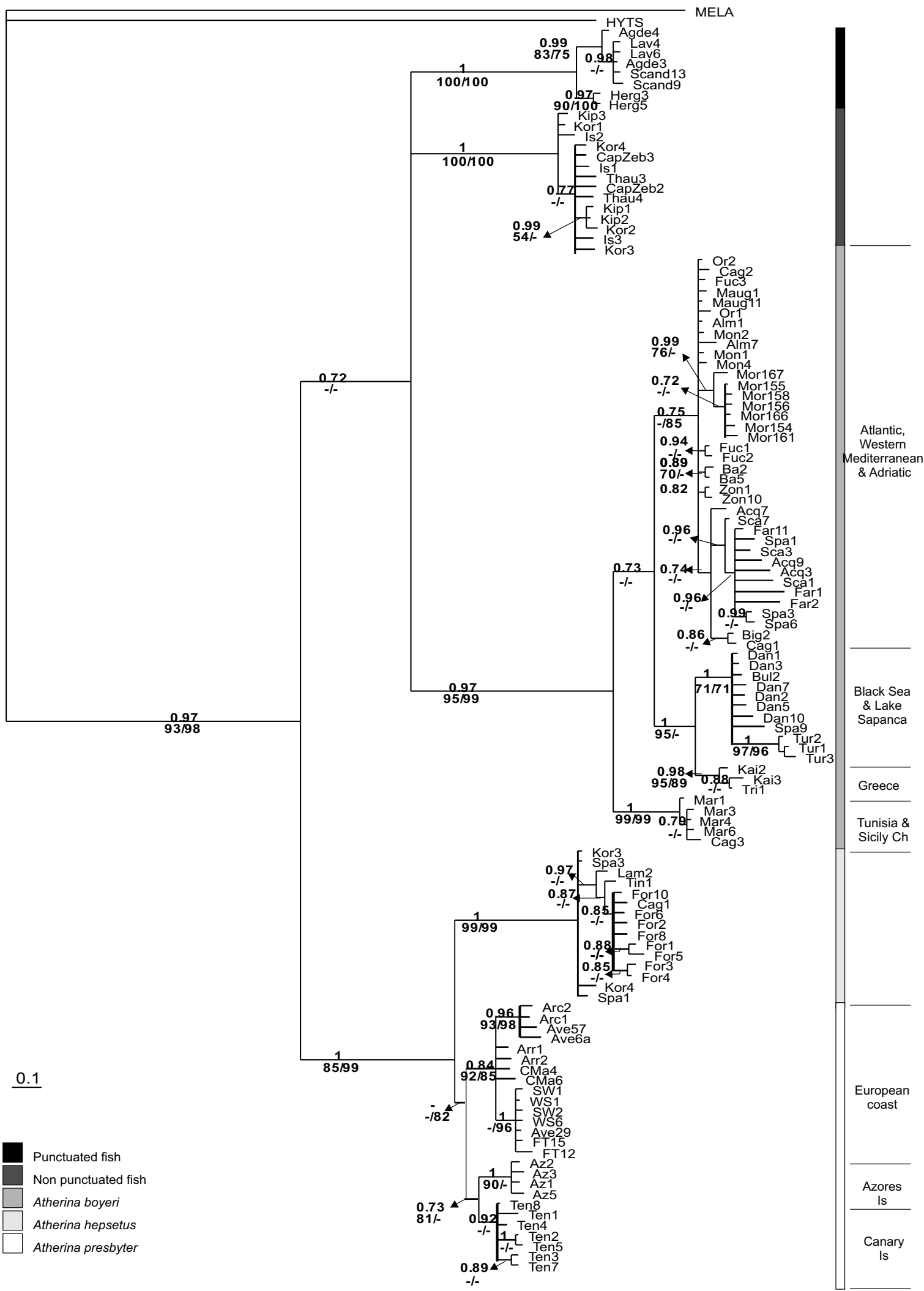

Fig. 2. Phylogenetic relationships within Atherina for the concatenated data of the $12 \mathrm{~S}$ and control region. For each branch, numbers above represent the posterior probabilities for Bayesian inference; numbers bellow indicate bootstrap values obtained for NJ and MP (values above 70\%). Melanotaenia lacustris (MELA) was used as outgroup and Hypoatherina tsurugae (HYTS) was added to the ingroup to see if all the fish of the genus Atherina emerged in a single clade. NJ was constructed with $\operatorname{TrN}+\mathrm{I}+\mathrm{G}$ model [proportion of invariable sites $(i)=0.4456$, gamma distribution shape parameter $(\alpha)=0.4837$ and transition/transversion rate $(t i / t v)=4.5641]$ and the MP presented corresponds to $t i l t v=5$. The haplotypes labels are indicated in Table 3 (electronic supplements). 
and Azores, however, show a clear differentiation and deserve further attention. As there are no genetic data on the West African A. lopeziana, doubts could arise on the identity of this Canarian fish. Additional taxonomic work is also needed in the Macaronesian islands and the African coast before we can achieve a complete phylogeny and proper taxonomy of the genus Atherina.

The emergence of $A$. boyeri as a complex clade with clear geographic subdivisions is also confirmed by our data. This fact is probably related to the distinct life cycle of this species which is, among the five here described, the one most associated with more fragmented environments (lagoons, estuaries and freshwater bodies). The fragmentation of these habitats together with the low dispersal ability of the species is probably responsible for the highly structured phylogeographic pattern observed. A distinct group, probably south Mediterranean, was recovered from Tunisia and the Sicily Channel. In the north, a large group is centered in the West Mediterranean, ranging into the adjacent Atlantic rivers and into the Adriatic Sea. Finally an eastern group includes a subdivision in the Aegean Sea and a distinct subgroup in the Black Sea, the Danube Delta and the freshwaters of Anatolia, the latter corresponding to what some authors called A. mochon pontica (e.g. Dobrovolov and Ivanova, 1999).

Finally, the punctuated and non-punctuated groups were confirmed and it was shown that their separation from other Atherina clades was a deep event, of a magnitude comparable to that separating $A$. presbyter from A. boyeri.

In summary, we can state that $A$. boyeri sensu Kiener and Spillman (1969) is polyphyletic encompassing three distantly related clades (Table 1). One includes what we labeled as non-punctuated, is typically marine, and is spread all over the Mediterranean Sea. A second clade includes what we labeled punctuated fish and is spread throughout the western Mediterranean in marine conditions. The third clade, we labeled $A$. boyeri is a brackish/ freshwater clade spread from Western Europe and Morocco to Turkey in estuaries, rivers, lagoons and lakes, and has a clear geographical subdivision. The differences either in color pattern or ecology combined with the large genetic distances strongly suggest that these clades are three valid species.

\subsection{Biogeographical implications}

From a biogeographic perspective a remarkable feature emerging from the present study is the relatively high proportion of Mediterranean endemic Atherina species. Out of the five major clades identified, three are endemic to the Mediterranean Sea and the brackish/freshwater $A$. boyeri ranges extensively around this sea with a small extension to the North-eastern Atlantic rivers and lagoons.

There is no calibrated molecular clock for the CR of Atherina. If we adopt the $10 \%$ divergence rate suggested by Bowen et al. (2006) we find that the corrected distance between $A$. hepsetus and A. presbyter corresponds to a divergence time of less than a million years. Such a pattern is consistent with a split of an ancestral population caused by the Pleistocene glaciations with survival in at least two refugia: one in the Mediterranean and one or more in West Africa/Macaronesia. Indeed, during glacial maxima, polar to cold temperate conditions occurred as far south as the Iberian Peninsula and even affected the shores of Northwest Africa. In West Africa, Madeira and part of the Canaries, as well as in pockets within the Mediterranean, warmer waters persisted, which caused vicariant speciation of many species pairs, with one member in West African Macaronesia and the other in the Mediterranean (e.g. Domingues et al., 2006). It is likely that $A$. hepsetus is a Mediterranean derivative of a mainly Atlantic stock, an interpretation favoured by the much higher genetic diversity of $A$. presbyter when compared with $A$. hepsetus.

The western European and Moroccan A. boyeri belongs to the same clade that occurs in the Western Mediterranean and Adriatic Seas and probably survived in the Mediterranean area re-invading Atlantic rivers and lagoons after the last glaciation (Francisco et al., 2006).

The remaining phylogroups included in $A$. boyeri, as well as the marine punctuated and non-punctuated fish, are Mediterranean. It is likely that regional "pockets" of atherinids may have become isolated when the Mediterranean underwent serious fragmentation of its circulation. Two scenarios are compatible with the hypothesis outlined above. The glacial peaks caused drastic sea level drops and reduced warm water to a number of scattered "pockets". Alternatively, the Messinian Salinity Crisis fragmented the Mediterranean into a number of water bodies of very variable salinities (Bianco, 1990). Perhaps A. boyeri, with its marked preference for brackish and freshwater, is a Paratethys immigrant into the Mediterranean. Its range, from the Caspian and Black Seas to the Atlantic, is suggestive of such a possibility. Only the calibration of a molecular clock for Atherina will help to access both the Messinian and Pleistocene scenarios.

\section{Acknowledgments}

We acknowledge grants to S.M.F. (SFRH/BD/12653/ 2003), S.S. (SFRH/BPD/14981/2004) and A.L. (SFRH/ BPD/18067/2004) from FCT. R.C. financed by FCT annual funds to CCMAR. The UIE-ISPA and IMAR/DOP are funded by FCT through the pluri-annual and programmatic funding scheme (FEDER) as research unit \#331/94 and \#531, respectively. IMAR/DOP is also funded by DRCT as Associate Laboratory \#9. This study was funded by the research project PNAT/1999/BIA/15017. The authors are grateful to F. Almada, M. Henriques, C. Faria, V. Domingues, R. Beldade, N. Monteiro, A. Pereira, J. Robalo, M. Goran, J. Freyhof, C. Mazzoldi, M. Krakau, E. Tosi and P. Afonso for their help in providing samples, field and laboratory work and comments on the ms. 


\section{Appendix A. Supplementary data}

Supplementary data associated with this article can be found, in the online version, at doi:10.1016/j.ympev. 2007.12.009.

\section{References}

Astolfi, L., Dupanlouop, I., Rossi, R., Bisol, P.M., Faure, E., Congiu, L., 2005. Mitochondrial variability of sand smelt (Atherina boyeri, Risso, 1810) populations from North Mediterranean coastal lagoons. Mar. Ecol. Prog. Ser. 297, 233-243.

Bianco, P.G., 1990. Potential role of the paleohistory of the Mediterranean and Paratethys on the early dispersal of Euro-Mediterranean freshwater fishes. Ichthyol. Explor. Freshw 1, 167-184.

Bowen, B.W., Muss, A., Rocha, L.A., Grant, W.S., 2006. Shallow mtDNA coalescence in Atlantic pygmy angelfishes (Genus Centropyge) indicates a recent invasion from the Indian Ocean. J. Hered. 97, 1-12.

Dobrovolov, I.S., Ivanova, P., 1999. Biochemical genetic comparison of the Atherina boyeri and Atherina mochon pontica (Pisces, Atherindae). Folia Zool. 48, 55-60.

Domingues, V.S., Santos, R.S., Brito, A., Almada, V.C., 2006. Historical population dynamics and demography of the eastern Atlantic pomacentrid Chromis limbata (Valenciennes, 1833). Mol. Phylogenet. Evol. 40, 139-147.

Excoffier, L., Laval, G., Schneider, S., 2005. Arlequin ver. 3.0: An integrated software package for population genetics data analysis. Evol. Bioinf. online 1, 47-50.

Farris, J.S., Källerjö, M., Kluge, A.G., Bult, C., 1995. Testing significance of incongruence. Cladistics 10, 315-319.

Felsenstein, J., 1985. Confidence limits on phylogenies: an approach using the bootstrap. Evolution 39, 783-791.

Francisco, S.M., Cabral, H., Vieira, M.N., Almada, V.C., 2006. Contrasts in genetic structure and historical demography of marine and riverine populations of Atherina at similar geographical scales. Estuar. Coast. Shelf Sci. 69, 655-661.

Gourret, P., 1894. Les pêcheries et les poissons de la Méditerranée (Provence). Bailliére et Fils. Paris, 360 pp.

Henriques, M., Lourenço, R., Almada, F., Calado, G., Gonçalves, D., Guillemaud, T., Cancela, M.L., Almada, V.C., 2002. A revision of the status Lepadogaster lepadogaster (Teleostei: Gobiesocidae): sympatric subspecies or a long misunderstood blend of species? Biol. J. Linn. Soc. 76 327-338.

Huelsenbeck, J.P., Ronquist, F., 2001. MRBAYES: Bayesian inference of phylogeny. Bioinformatics 17, 754-755.

Kiener, A., Spillman, C.J., 1969. Contribution à l'étude systématique et écologique des athérines des côtes françaises. Mem. Mus. Natl. Hist. Nat. - Ser A 60, 1-74.
Kishino, A., Hasegawa, M., 1989. Evaluation of the maximum likelihood estimate of the evolutionary tree topologies from DNA sequence data, and the branching order in hominoidea. J. Mol. Evol. 29, 170-179.

Klossa-Kilia, E., Papasotiropoulos, V., Tryfonopoulos, G., Alathiotis, S., Kilias, G., 2007. Phylogenetic relationships of Atherina hepsetus and Atherina boyeri populations from Greece, based on mtDNA sequences. Biol. J. Linn. Soc. 92, 151-161.

Klossa-Kilia, E., Prassa, M., Papasotiropoulos, V., Alahiotis, S., Kilias, G., 2002. Mitochondrial DNA diversity in Atherina boyeri populations as determined by RFLP analysis of three mtDNA segments. Heredity 89, 363-370.

Kottelat, M., 1997. European freshwater fishes. Biologia 52 (Suppl 5), 1271.

Maugé, L.A., 1990. Atherinidae. In: Quire, J.C., Hureau, J.C., Karrer, C., Post, A., Saldanha, L. (Eds.), Check-list of the fishes of the eastern tropical Atlantic (CLOFETA), vol. 2. Paris, pp. 604-605.

Ostellari, L., Bargelloni, L., Penzo, E., Patarnello, P., Patarnello, T., 1996. Optimization of single-strand conformation polymorphism and sequence analysis of the mitochondrial control region in Pagellus bogaraveo (Sparidae, Teleostei): rationalized tools in fish population biology. Anim. Genet. 27, 423-427.

Posada, D., Crandall, K.A., 1998. Modeltest: testing the model of DNA substitution. Bioinformatics 14, 817-818.

Quignard, J.P., Pras, A., 1986. Atherinidae. In: Whitehead, P., Bauchot, M.L., Hureau, J.C., Nielsen, J., Tortonese, E. (Eds.), Fishes of the North-eastern Atlantic and the Mediterranean. UNESCO, Paris, pp. 1207-1210.

Ronquist, F., Huelsenbeck, J.P., 2003. MRBAYES 3: Bayesian phylogenetic inference under mixed models. Bioinformatics 19, 1572-1574.

Sambrook, E., Fritsch, F., Maniatis, T., 1989. Molecular Cloning, second ed. Cold Spring Harbour Press, Cold Spring Harbour, New York.

Swofford, D.L., 2000. PAUP* Phylogenetic Analysis Using Parsimony (*and other methods), Version 4. Sinauer Associates Inc., Sunderland, MA, USA.

Tamura, K., Nei, M., 1993. Estimation of the number of nucleotide substitutions in the control region of mitochondrial DNA in humans and chimpanzees. Mol. Biol. Evol. 10, 512-526.

Thompson, J.D., Gibson, T.J., Plewniak, F., Jeanmougin, F., Higgins, D.G., 1997. The Clustal X windows interface: flexible strategies for multiple sequence alignment aided by quality analysis tools. Nucleic Acids Res. 25, 4876-4882.

Trabelsi, M., Gilles, A., Fleury, C., Mâamouri, F., Quignard, J.P., Faure, E., 2002a. Atherina punctata and Atherina lagunae (Pisces, Atherinidae), new species in the Mediterranean Sea. 2. Molecular investigations of three Atherinid species. C. R. Biol. 325, 1119-1128.

Trabelsi, M., Faure, E., Quignard, J.P., Boussaid, M., Focant, B., Mâamouri, F., 2002b. Atherina punctata and Atherina lagunae (Pisces, Atherinidae), new species in the Mediterranean Sea. 1. Biometric investigations of three Atherinid species. C. R. Biol. 325, 967-975. 